書 評

\section{編 集小保内虎夫}

\section{応用実験心理学}

\section{A. Chapmanis, W. R. Garner, and C. T. Morgan}

(Applied experimental psychology : human factors in engineering design. 3 rd Print. New York: John Wiley \& Sons, 1954, pp. 434)

本書の初版は 1949 年に出ており, 人間工学関係の概 説書としては草分けに属するものである，我国でも，既 にこの分野の研究はかなり進められており, 数冊の単行 本も公刊されている現状から, 時代遅れの感もあるが本 書に示されている行き方が人間工学発展の一つの源流を なしているのであるから，ここにとりあげるのも無意味 ではないであろろ。

まず簡単に内容を見ることにする，第 1 章「序論」で は，この分野を意味する各称の数多いことをあげ，応用 実験心理学を採用するが，どれも実質的差異はなく，機 械の設計拉よび操作を, もっとも人間にとって使いやす くするための科学のことだと規定する. 歴史的背景を概 観したらえで, 実験心理学の応用的性格を前面に出して いる. 第 2 章「簡単な統計」は表題通り, 代表值, 散布 度䏡よび相関係数の求め方をレーダ一読みとり值を例と して述べている。第 3 章「統計の使用」では射撃成績を 例として用い，変動の検討がェラ゙ーの種類とその原因の 発見, それらの人間一機㭜系への相対的影響の分析に役 立つことを説明する. 第 4 章「われわれは如何に見る か」では視覚についての基本的事実が述べられている。 色覚と光刺激の関係とその物理特性の表記法, 昼間視・ 夜間視をはじめ視感度および視力に影響する諸要因があ げられ，眼球運動や錯視にも触れている．第 5 章「計器 ダイヤルと見やすさ」では航空計器類の読み誤りを減ら すことを目的とした諸研究が紹介されている：読みとり の速さ掞よび正確度を指標としたいくつかの実験を挙げ て, ダィヤル設計を改善すれば誤りを激減できるとし て, 設計上の諸要因を検討している，第 6 章「視覚表 示」では視覚表示系での種々の問題点を扱っている. 問 題は多岐にわたって抢り, 共通の改良原理はほとんど見 出されていない，絵画表示が時には記号表示よりもよい とか, 計器等に使う文字や数字の型について改良すべき 点などが述べられている. 第 7 章「われわれは如何に聞 くか」では第 4 章と対応して, 物理音の記述法にはじま り聴覚の基礎事実が書かれている. 第 8 章「音声」は,
人声に関する心理・生理的基礎研究の概観である。第 9 章「音信号系」は音信号の人間工学的実用例をとりあげ て, 強度, 周波数, 持続時間, $\mathrm{S} / \mathrm{N}$ 比などと弁別の関係 怙よび弁別改善のための工学的工夫との関係が述べられ ている.ここでとりあげられた例はラジオ，レンジ信号 およびフライバーであって, ぞちらも航空機管制, 誘導 に用いられるものである. 第 10 章「われわれは如何に 運動するか」では人間の動作についての知識が列挙され るが，その扱い得ているのは手先と腕の運動についてだ けである。位置づけ反応, 反復動作; 追跡運動に含まれ る動作の速度, 正確度が測られている。それらには運動 の方向, 距離, 摩擦や慣性, 力の強さ, 対象物の動き等 が影響している．第 11 章「人間が使うための統御機 器」で, 人間が機械使用中に犯す誤りの種類と, 誤りを 排除するための二，三の方法が述べられている．統御機 器の位置, 大きさ, 型拈よび色などによるコーディング の問題, 人間が用いる力と機器の動きの適切な関係など によって誤りの排除ばかりでなく, 能率の増進ができる ことを見ている。第 12 章「作業配置」では, 作業員が 立って働くか坐って働くか, 座席の設計は快適か, 道具 や統御器類の位置は, 等々の作業能率との関係が述べら れている. 第 11 章, 12 章は時間研究, 動作研究の資料 に主としてょっているのである。第 13 章「作業と休 息」では疲労の徴候, 疲労による成績の減退, 誤りの増 加, 感情の動摇, などを見, 休息効果と適当な作業時間 にも触れている．第 14 章「作業環境」では機械設計の 改善だけではゼめで, 人間を最も能率的に働かせるため の環境特性を考虑ず゙きだと言う。温度, 湿度, 振動, 騒音, 照明などと能率の関係が見られている。

以上が大体の内容である。さて, 本書の母体は, 著者 らがアナポリス海:軍兵学校で 1947 年に研究科の工科専 攻生を対象として行なった工学心理学の構義録である. その後 1951 年までの資料が加光られているが，な打次 のような特徴が見られる。

すなわち，1）読者対象を心理学専攻者以外において いる，2）統計, 視覚, 聴覚等についてのきわめて初歩 的記述に，各 1 章以上を費して括り，これが全体の $1 / 3$ 強に当る. 3) すぐ役立つ事実, 知識の紹介を主眼とし, 研究領域の規定や研究法の検討は副次的である。4)本 書成立の背景を反映して, 引用実験例は軍関係とくに航 空機関係のものが多い，5）章の構成も片寄っており， 体系的でない，6）参照資料として採用されているのは, ほとんど伝統的実験心理学の方法の枠内にあるもので, 戦時, 戦後を通じて著るしく発展して来た新分野の業績 は採用されていない。

さてこれらの5ち，1，2 は概説書として当然とも言 えるが，これを人間工学の本としてみればやや基礎的記 述が多過ぎる観がある。心理学以外の人を対象とした特 


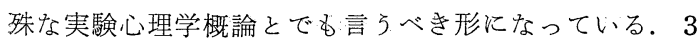
は 6 とも関連するが，概説書としての性格以上に著者ら の基本的立場を示しているよ5に思われる。人間工学を 心理学者が能動的に推進する学問分野としてでなく, 産 業界その他からの要請によって既得の方法, 知識の伝 授，応用を行なら分野として报っているように思われ る.この感じは別稿の「人間工学の研究法」でも5かが われるであろ $5.4 ， 5 ， 6$ 火ついては本書成立の時期, 背景を考学ると理解できるが，ただ各章の表題が，たと 壳ば「計器ダイヤル……であり，「視覚表示」である ように，材料中心であり，人間一機械系の機械側に寄っ ている. 别稿の McCormick のものなどでは主として人 間の performance の側から構成されて拈り，この点に も著者らの考え方が現われていると言える。さて本書の 表題は応用実験心理学なのであるから, 伝統的実験心理 学に依存するのも一つの立場とは言えよ5。一しかしたと えば Werner の sensory-tonic field 説も1945 年頃か ら、末と末った形ではないまでも発表され始めて括り, その他にも心理学の新しい動さの中で人間工学と関係す るものが全然反映されていない点に問題がある。現在の 問題としては人間-機械系の発達は急速で, 単に工場や 交通機関, 軍事ばかりでなく日常生活でも数多くのかつ 複雑な人間機械の接触点が生じつつあるのだから, 既成 の方法, 知識ばかりでなく, 進んで他分野との協調の上 で新研究法を開拓しなければならないであろう。既に, 照明, 測色学, 色彩調節等は物理心理的接近がかなり進 んで叔り, 情報理論も実験心理学的研究に数多く採用さ れている．感覚尺度作成を中心とした尺度理論も当然人 間工学でとりあげられるべきであるう。身体計測から宇 宙医学に至る医学・生理学的接近や環境工学も比重を増 しつつあり, 更にインダストリアル・デザイン畑での研 究などを加えると，綜合さるべき知識，技術の範囲はき わめて広いものになる。こうなっても, 人間工学, 工学 心理学, 生機械学, 応用心理物理学, 心理技術学などの 用語が，いずれる応用実験心理学と大同小異であり，応 用実験心理学が最も適用だと言ってよいかどうか間題で あろう。要するに, 本書は当時の研究水準での, 注ぼ確 立された事実の紹介に主力を拈き，材料が末梢的に過ぎ るきらいがある。人間工学のような未成熟な新分野を报 丂以上，概論書といえども，将来の発展を見と执して， 有用な新研究法, 新分野の知識をとり入れた指導的性格 を持ってょいであろう。

\section{東京教育大学 加賀秀夫}

\section{人間工学研究法}

\section{A. Chapanis}

(Research techniques in human engineering. Baltimore : Johns Hopkins Press, 1959)

著者は別項で紹介されている「応用実験心理学」の著 者でもある. 1954 年, 機械設計の人間工学に関する連 合指導委員会実行会議 (The Executive Council of the Joint Services Steering Committee for the Human Engineering Guide to Equipment Design) から人間工 学研究法のとりまとめを委嘱され，その結果は「The design and conduct of human engineering studies」

（1956）の非公式報告であるが，その後好評を得て多少 改訂した上，本書を出版したものである。人間工学は機 械と人間との間に括ける設計や操作上の実際問題から生 じたのである，技術者の立場や習慣からすれば，そのよ らな問題に際して, 平常多くの場合, 物理, 化学, 工学 などのハンドブックないしは規格を参照して資料を得る ように，人間工学ハンドブックの類がほしいのである が，そのような要求を満足し得るだけの十分な資料はき わめてすくない状況である。それは人間を対象とした科 学が, 物理や化学とらがった特殊な復雑さをもっている からで，それが機戌設計にいつも応用できるような画一 的な資料を得ることを困難にさせているのである。そこ で人間工学では実際的状況に応じた多くの実験研究が一 層必要とされるのである。すでに二三の書によって人間 工学が有意義な一領域をなしてきた段階に打いて，人間 工学研究のためのいわば方法論上のハンドブックと見ら れる本書が与えられたことは時宣を得ている。本書はめ きらかに心理学以外の人間工学関係者一般をふくめた人 々を相手に書かれている。しかも人間工学のかなりの部 分は実験心理学である. そのため人間工学研究法といっ ても心理学からみれば特に目新しいるのはないといって よいと思らが，同時に人間機械関係というややひろい問 題領域から人間科学の特殊性, それは心理学にとっては 当然で，ときとして無反省になってしまうことである が，それをあらためて認識させてくれるものともいえ る. 第 1 章はその意味に和いて人間研究の特殊性複雑性 という困難な面と, その対策として人間行動の科学への 研究対象の転換, オペレイショニズムなど, 現代心理学 の方法上の一般的動向が概説されている.

第 2 章以下は各種研究法が述べられる。まず人間機械 関係場面の直接観察法である。これは従来から動作時間 研究といって経営面の資料としての職務分析に利用され てきたるのであるが，そこでは時間研究が主たる意味を るつのに対して，人間工学としては動作分析が重要であ る。直接観察法は現場に括いて研究者自身が人間機械関 
係の問題点を発見するための重要な役割をるち，多くの 場合，問題点の解明がただちに解決策を示するのであ る.チエック・リストのようなものから映画記録にいたる まで，平面的立体的各種分析法が記されている，第 3 章 は事故分析である。これは現場調査による問題点の発見 と是正を目的とする点で直接観察法に準ずるものである が，直接観察法のよ5にあらかじめ計画されたものでな く, かつ一回的事実である点から調査はむずかしく慎重 を要する。そこで事故調查にはアメリカ民間航空管理局 や，アメリカ規格協会なぞがそれぞれ手続上の規定を設 汀ている.人間工学々事故分析の関係は，人体生理学が 疾病の研究から多くの知識を得るのに似ている. 実際に 事故にいたらないでも，事故を和こす潜在的可能性が間 題なので山るから，事故を和こしそうとなった事例の研 究も同様に有効である。これを near-accident study と呼ぶ。さらに機械操作でよく特こる誤りを調査し，事 故の遠因々なる人間機械関係要素を発見するのるよい. これは critical incident study と呼ばれる。

第 4 章から実験的研究にはいるのであるがその橋わた しとして統計执よび統計的検定について述べられる。す なわち初歩的統計から $t$ テスト， $F$ テストを応用した 検定まで手短かに説明されるが，心理学研究者にとって は周知の事である。第 5 章は実験的方法について，人間 の応答は特有な測定值の变動々その統計的処理法, 系統 誤差のカウンター・・゙ランスイング,ないし実験系列のラ ンダマイズイングなど基本的な実験心理学の技法から, 測定值の差の検定, 多变数の分散分析, ラテン方格などの 実験計画が各種の実験例とともに述べられる。これらの 技法も大事であるが，人間工学の実験研究に执いて特に 問題なのは装置の simulation の程度であろう。つまり 実験場面をどの程度実際に似せるかということである。 研究結果の適用性から見れば実際場面で奏験するにこし たことはない、シミュレイションでは実際の条件を全 部もり込むことはできないし被験者の態度も実際とはち がうであろう。しかし同時に実際場面では統制できない 条件が多くて実験的研究は最も大事な条件統制による分 析ができない。また被験者の側についても実験が自己の 技能成續評定と勘ちがいされたり，学資関係のむずかし い所では組合側が非協力的であったりして，モチヴェイ ションにる複雑な要素が加わる。何より実際場面の実験 は高価である。一方シミュレイションによる実験結果も 多くの場合かなりの実用性をもっていることが認識され ねばならない，たとえばAとBについて，AがBより 「どのくらい」すぐれるかといら閣題は実際場面でない と結果はでない。しかしAとBと「どちら」がすぐれて いるかというのであれば結論はシミュレイションでも実 祭場面でも，末ずちがいはないのである。攵のような例 を著者はいくつかあげている，要するに各種の条件を考
虑して最適シミュレイションをとるわけであるが，人間 工学が別名応用実験心理学として成り立つかどうかはこ の辺の事情にもかかっているのであるから，もうすこし 多くの実験例の分析と評価が欲しいところである．第 6 章は前章のつづきのようなもので, 実験独立変数, 從属 変数の設定に関する諸注意, 他の統制さるべき変数群, 特にモチヴェイションの問題, インストラクションの注 意, 統制実験（これは生物科学特有である）の必要性が 述べられる. 被験者のとり方についての各種抽出法が説 明されるが，特に偶然抽出（fortuitous sampling）（た またま手近かな人を被験者とする）が技術者同志の間で 㣘こなわれることもいましめると同時に，同様な事実は 心理学に为めって, 現代アメカ心理学は the psychology of the American College sophomore だとら酷評を めげている。な特，人間工業的間題はすでに心理学者が かなり研究しているものでめるから，まず関係文献をし らべることをうながし，その情報源として，Handbook of Human Engineering Data(Tufts College, Institute of Applied Experimental Psychology), 1952, A Human Engineering Bibliography (McCollom, I. N. \& Chapanis, A.), 1956 の他, Ergonomics, Human Factors, Psychological Abstract などの刊行物をむげてい る.

第 7 章は実験心理学のもっとも基本的な測定法として 心理物理的な方法が述べられる。一般に心理物理学では 被験者が単なる検出者 (detector) ないしナル・インス トルメント (null instrument) であることから説き始め ていることはいかにも技術者向きの説明として执もしろ い. 調整法, 極限法, 恒常法などのほか, これらの方法 で注意すべき空間錯誤，時閒錯誤などの注意があり，実 験心理学にとっては事新しいものはない，最終章すなわ ら第 8 章は音声通信路特性の音節テスト法 (Articulation testing method), 別名 intelligibility testing $飞$ ついてでめる．音声通信テストには使用すべき標準的用 語がきまっていて ICAO (International Civil Aviation Organization) の Word Spelling Alphabet とかハバード大学心理音響学研究所のノンセンスシラブルその 他が岕げられている。この章は前の各章に対してやや異 質的な感がするのであるが，方法論という立場から見る ならば音節テスト法は知覚, 記憶さらには学㥜といった ような一連の高等精神機能の心理実験の部類に属するる のとして論ずべきであるし，通信系の人間工学的問題と いう特定事項を附録的につけたるのであるならば，テレ ビジョンなどの画像伝送系についても多くの問題が岁る ので欠かせないところである。

さて既述のように本書は主として心理学以外の人間工 学関係者を対象にして，人間工学の主要な方法である現 場調査と実験心理的研究法とを概説したるので，そのた 
めの目的は一応達している。しかし人間工学は現在, 応 用心理学の一分野をなし, 今後この方面の心理学者の研 究活動が軌道にのってくるものとすれば，心理学徒のた めの人間工学研究法が欲しいところである。そのために は実験心理学研究法自体もさることながら，それ以上必 要なことが他にあるのではないかと思5。その意味では 本書の 1,2 章は心理学にとって有益である. しかしそ の他, 人間-機械系をむすぶ重要な理論として, 通信理 論, 制御理論, 女るいは線型計画法などの概念や关机に 必要な数学的解析化関する心得が人間工学心理学にとっ て望ましいことである。それらのことる心理学にとって は人間工学研究法の一部としてふくめたいのである。た だ本書は, 人間工学成立の一時期に扮いて, 人間工学の 連合委員会に対する心理学者からの報告である。したが って人閐機械系という新らしい中間領域に拈いて, 実験 心理学研究法の重要性を自他ともに認識せしめるとい5 役割をるったものと解することもできる.

\section{東京教育大学 金子隆芳}

\section{人 間 工 学}

\section{E. J. McCormick}

(Human engineering. New York : McGrow-Hill, 1957)

本書は戦後 10 年を経て書かれたもので, 戦中戦後に 打ける機械技術の著るしい発達にともなって強く要請さ れるょらになった人間工学の成果をたどり，体系化した ものである。

ところで，人間工学の体系は，工学をはじめとして， 物理学, 人類学, 生理学, 心理学など多くの隣接諸科学 の協力によって作りあげられたものである。本書は，当 然のことながら，心理学の側から，心理学的な面に重点 を扰いて書かれたるので，その対象としている読者む， 心理学以外の人間工学関係者となっているが，人間工学 を「人間の行な5作業や労働環境を，人間の感覚的・知覚 的・知的・身体的及び其他の諸性能に適合させること」 と考光る以上，そこに打ける心理学の役割は極好大き なものであって，必ずしも偏ったものとはいいきれな い、ことに著者は，本書を著わすにあたって，ただ単に 人間工学にいくらかでも関係のある基礎的な実験や研究 をすべて生のま要約して示すといらような態度や，そ の反対に，基礎的なるのは無視して「拈手本」式にその 場ですぐに役立つようなるのだけを吸い上げるなどとい ら極端な態度を避けている。前者のような態度では, 他 の分野の読者に理解できず，また，それらの研究がごの ように人間工学に役立つのかも知ることができないから であり，後者の方法によると，読者は人間の能力やその
限界について何の知識も得られないし，基本的な原理を 知らないために, designされたものに対して正しい許 価ができないからである。著者は「人間がそれを使用す るのだといらことを考慮に入れて designすす場合，む 乙彼が, 有機体としての人間の機能が外界からの情報 （information）を受けとって決定し，它れに基づいて行 動するという過程をどのように行なっているかというこ とを理解すれば，一層より成果をあげることができる! と述べている: そこで本書は次のような態度をもって書 かれた。

1. できるだけ広い分野からの研究を紹介し，その内 容について，諸者がそれぞれの立場から批判できるよう に，方法と結果をなるべく詳細に述べる.

2. 研究法がはっきりしない場合には，炎の研究の結 果の応用の可能性を示す.

3. 作業場面に求ける人間の機能がよく理解できるよ 5 亿, 視覚, 聴覚, motor activity の過程に関する章を 設ける。

4. 心理学で用いられる特殊な用語を最少限にとどめ る.

このような著者の態度によつて, 本書はかなり公平な 人間工学の手引となっている.

本書は，その内容から大きく 7 つの部分に分けること ができる。まず，第 1 章「序論」では人間工学の目的・ 方法について論じ，つぎに第 2 章から第 5 章までの 4 つ の章で視覚の問題を, 第 3 に, 第 6 章から第 8 章までで 聴覚の問題, 第 4 飞第 9 章と第 10 章とでその他の諸感 覚を取り报い, 第 5 に第 11 章から第 13 章まで motor activity とそれに要する空閒について述べている. 第 14 章, 15 章とで以上の成果から機械その装置の配置の問 題を論じ，最後の第 16 章で結論を述べる.

さて，以下具体的にその内容を検討して見上弓。

第 1 章「序論」では，人間工学に执いても他の科学々 同様, 組織的な研究によって数量化することが考光られ る。ここでは, そのために統計的な分析の必要が説か れ，簡単な統計の基礎が述べられている。本書が対象と する読者から考兄て，この統計法は余りにす初歩的にす ぎるのではないかと思われる。るっと高度な実験計画や 推計学の方法を示すべきであらう。また，人間工学の研 笢は，実験室拉よび作業場面の両方でなされるが，これ はそれぞれの問題によって選ばれる必要のあることが主 張されている。また研究の可能性る一義的には解釈でき ないことが多いので，その研究の行なわれた条件等につ いての理解が必要である。本書はこの点を繰り返し强調 している。これらは当然のことのようでありながら，と るすると実際の応用場面飞招いては忘れられがらのこと である。

第 2 章「光と視覚」では，光と視覚過程执よび visual 
accuity 規定する条件を従来の精神物理学の成果から 述べている，第 3 章「照明」では作業場面における照明の 効果を種々の面から考察している．はじめに照明の適当 な強さについて 5 種の規準をあげているが，そのいずれ む決定的なるのとはされていない.つぎに眩しさ (glear) についてその原因，影響掞よび解消の方法が具体的に示 される，その他，道路や八イウェイの照明と交通事故と の関係など，我国でも大いに参考になろ5。第 4 章「視 賞的な表示 (display)」で扱かわれる問題は，第 2 次大 戦中に著るしく発達した航空機に関して多くの研究がな されている，それらの研究は，読及誤りの分析を出発点 としているが，これらの分析は，これまでの章で述べら れた視覚の基礎的な研究との間に多少のギヤップが感じ られる。第 5 章「色」は，主として色彩調節の問題であ るが，単に心理学的なるのだけでなく，生理学的な面で の影響にも言及している。

第 6 章「音と聴覚」では視覚の場合と同様基礎的な問 題を报つている，第 5 意「聴覚的コミュニケイション」 は音声によるコュミニケイションを話者と聴者の両面か ら分析している。しかしこれは主として音声学的な分析 で, コュミニケーションの内容や意味との関係は論じら れていない。その他言葉によらない聴覚的信号のインフ オーメイションの方法が述べられている. この問題は, 人間工学以外の問題としても興味深いものである。第 8 章「騒音とその効果」では，造船所のドラム工などの聴 覚的障害の例をはじめ，そのような生理的な障害とはな らないまでも，作業能率の低下の原因となる騒音の分析 を行なってその対策を述べている，我国でも基地周辺の 学校の騷音対策や工場の騷音などの問題に参考となる。 ここではさらに, back ground music の効果も述べて める。

第 9 章「環境条件 (atmospheric conditions)」では, 気温，湿度，酸素欠乏等の人体（特に作業中の人間の） に及ぼす影響を述べている。最近話題となった不快指数 と関連させて読むと與味深いものがある。第 10 章「人 体の方向づけ (orientation) と重力」は，まず平衡感覚 について解説し, 宇宙計画におけるGの問題に発展す る. 種々の姿勢で, 各方向から働く重力に対する抵抗力 を詳細に検討している。

第 11 章㘧よび第 12 章に特いては「人間の motor activity」の問題を取り报 弓。手や足の作業に拈いて, 最も早く, 正確に, 力強く運動の行なわれる方向, 距離 等が示されている，反応時間や協応動作の問題も重要な るので岀る。この場合には，他の場合と比較して，個人 差が著るしいのでその点に注意を向けている，著者によ れば，全体の 95\% が使用できる点を規準として，残り の $5 \%$ は無視してよいるいう.

第 14 章「調節装置 (control) 表示器 (display) の
設計と配列」に抢いて，著者は 5つの原則をあげる. 例えば，1）機能の原則：同じような機能をもったもの をまとめて並べる，2）重要性の原則：最も重要な機器 （例えばダイヤル）は最も使い易い（見やすい）位置に おく，なぞである。これらの装置の間の相互関係は link value によって数量化される，そして著者は，機珹の設 計配列が，外見上の形にとらわれて「人間が使用するも の」といら基本的な原理を忘れてしまってはならないこ とを強調している、第 15 章「機械の配置」では主とし て作業員の「動線」の研究が述べられているが, 作業員 相互のコミュニケーションの問題や，作業場内での「視 線」の問題も取り上げられている。

以上の章では人間を中心にして，その機能を理解し， それに基づいて機械を改良していくことが考えられてき た．しかし第 16 章「機械と人間との関係」では，人間一 機械系という一つの大きな系を考劣ることの必要が主張 されている，そのような大きな観点に立って，はじめて 人間と機械とがその機能を最大限に発揮するようになろ 万。機械を操作する人間を機械との関係に扣いて把える 時，その機能も，人間だけを取り出した場合と当然異っ てくるに違いない，本書に叔いては，その具体的なるの は示されていないが，人間の働きを，情報の受信，態度 の決定，制御行動の 3 つに大別して考察の方向を示して いる、第 1 の問題では情報理論が有用なるのとなろ 5 . 第 2 の問題では，選択決定に要する時間の短縮すること の必要性が主張されている。制御行動に関しては，原則 として、コントロールの方向がなるべく一方向で行なわ れ，それによって生ずる効果の方向と並行していくこと が望まれている。

扣打よそ，本書の内容を述べてきたが，全体としての 読後感は, 心理学の基礎的な実験事実と, 実際場面との 間のギヤップがまだ埋められてはいないということで, しかるそのギヤップを埋める方向がはっきりしていない といら点である。それでも，従来，技術者が勘と経験に 頼って解決してきた問題に，かなり科学的，理論的な根 拠を与え，大いに参考にはなることである。

\section{東京教育大学 服部政夫}

\section{人 間 I 学}

\section{坪内和夫}

（東京 日刊工業 1961, pp. 284）

わが国に怙ける人閒工学の研究は, 田中寛一著：能率 研究一人間工学一同文館，1921）に遡ることもできる が，現代的な意味でのそれは，戦後の Human Engineering あるいは Engineering Psychology の他, 各種の名 称が附された主として米国の，次いで Ergonomicsと 
称する英国を中心とする欧州系の研究を指す，その紹介 は主として雑誌に掲載されていたところ, Woodson, W. E. の Human Engineering Guide for Equipment Designers (Univ. of California, Berkeley, 1954) が青 木・野本共訳：人間工学一装置設計者のための一(コ口 ナ社 1955) として刊行され, 次いで名取順一：経営の サイバネティックスー人間工学と疲労一(技報堂 1957), 三浦豊彦：人間工学（経営工学講座 共立出版 1958), 坪内和夫：人間工学（生産工学講座 日刊工業 1959), 倉田正一：人間工学（技報堂 1951), 坪内和夫：産業心 理と人間工学 (生産性ハンドブック ダイヤモンド社 1960), さらに本年に至り本書が上梓された。これらの 諸書は工学や医学の出身者によって執筆されているこ そ, さらにわが国での人間工学研究の成果が, 工学関係 誌に多く発表されていることは, 人間工学の発詳地とも いうべき実験心理学に, 関連諸科学, 特に工学が緊密な 連熬を要求している証左となろう。

本書の構成は 7 章に分かれ，人間と機械の結合につ き，多少の技法を交光ながら，考慮すべき基本事項を人 間工学的素養を持たない初心者にも理解しやすいよう， 豊富な写真入りで圧縮してまとめてある。

第 1 節「人間工学の内容」では，まず人間と機械のあ ゆみと題して人間観，機械観を土台にした思想的背景 に,つぎに人間工学形成の主因が実験心理学にあり, 医 学・生理学, インダストリアル・デザイン, 環境工学, 制御工学が副因であったことに加兑, 軍事目的により開 発された歴史的必然性, さらに現在の海外事情に触れて いる．第 3 節ではシステム・エンジニアリングの観点か ら人間工学の説明を試み, 単独の存在として解決される と思われていた現象や物件が，ある大きな目的の下に結 合されて，全体が有機的な連繁を保持しつつ，その目的 達成のために作動する集団である“システム”として考 慮される段階に至っていることを強調する，例えば自動 制御系に括ける調整部を人間に置換した手動制御系の総 合能率 $\eta_{S}$, 機㭜の能率 $\eta_{M}$, 人間の能率 $\eta_{H}$ とすれば $\eta_{s}=f\left(\eta_{M}, \eta_{H}\right)=f($ 機械出力/機械入力 + 人間出力/人間 入力）の関係式が導かれ，ここで設計不良の場合は $\eta_{H}$ がマイナスになり， $\eta_{M}$ あまたマイナス值になって事故 発生の原因となる。このとき直ちに $\eta_{M}$ がゼロになるよ うな設計が要求されることはもちろんである。

第 2 章から第 5 章までは「人間の研究」と題する 4 部 作である. 視覚, 聴覚执よびその他の感覚に加え, レオ ロジーを扱 5 第 2 章, 照明, 色彩, 温熱, 騒音, 振動, 大気中の有害物質, 気圧, 酸素量など環境条件を内容と する第 3 章, 人体測定, 作業域, 手・足の筋肉運動など 作業能の測定を扱 5 第 4 章といずれも多数の図表を雨入 して平易に解説を試みている。これらの計測法や計測值 は心理学, 生理学にとっては自明の事実であつて, 特に
新らしい資料とはいえないが，工学系の読者にとっては 必須の知識である.

「人間の研究」の終章としての第 5 章は, 從来の動作 研究, 時間研究と併せて反応動作を静置動作 Static Re. action, 反復動作 Repetitive Movement, 遂次動作 Serial Movement, 位置ぎめ動作 Positioning Movement 预よび追従作業 Tracking Movement, 補正作業 Com. pensating Movement, 混合作業 Combined Movement, オープン・ループ作業 Open Loop Movement を含も連続動作 Continuous Movement に分類し, そ れぞれに若干の数式を適用してヒューマン・ファクター の解析に試みている.さらに精神反応として脳波ならび に精神反射電流にも触れている.

第 6 章「人間・機械システムの設計と解析」は, 著者 のスペシャル・フィールドであるだけに, 生物科学系の 読者にとって本書の主要部として示唆されるところ大で ある。おず，人間・機槭システムの設計に先立ち，その 解析の必要性をD Dreyfussによる設計に必要な人間工学 的検討や動作経済の原則を基礎にして説明を加え，然る のち幾つかの立場で解析が進展する。「人間工学的解析」 では, この領域の独特の手法としてリンク解析法 Link Analysis と空間指数法 Index Method 触れる。前者 は著者考案の単式重要頻度解析法に則り, 人間・自動車 システムでの実例を挙げて説明する。この領域での研究 開発の目標は，手動制御システムに拈けるコントローラ 一のウエイト式頻度法を用いた解析にあろう。しかもそ こでのウエイトの与え方は, 心理, 生理学的見地だけで はなく, 工学的なそれと併せてシステム全体としての算 出が要求されよう，後者では，人間・機栈システムが情 報の授受に括いて理想的な形態であっても，そのシステ ムの占有する空間が過小であると，そのシステム全体の 活動が阻害される故に, 必要空間を人間密度指数 Index of Crowding, 可通性点数 Acessibility Score, 可通性 指数 Index of Accessibility, 歩行指数 Index of Walking, 可視性指数 Index of Visibility, 会話指数 Index of Talking などから, 最終的には総合指数で求 め, 設計の良否を計数化する方法であって, 各基礎指数 は数段階による評価形式をとるが，その評価基準の厳密 な検討が将来の問題として残される。「インダストリア ル・エンジニアリング的解析」では, 人間の動作そのむ のの解析法としての動作研究, 時間研究, Predetermined Time Standards 法, システム活動の流動過程の検知・ 分析の手法としての工程分析，ハンドリッグス Handligs, 運搬工程分析, 稼働分析, ワーク・サンプリング, 事務工程分析につきそれぞれ特異な内容とそれを表示す る符号が説明されているが，これらは現行の手法では既 に限界に達しているので, より分析的な次元での解析が 要求されよ5。「疲労による解析」で报うのは, 工学上 
の疲労ではなく、いわゆる産業疲労であるが，著者考案 の, 疲労測定器が注目を引く他は目新しい資料が見当ら ない、「制御工学的解析」では，エレメント中に人間を 含む手動制御システムに自動制御の手法を適用し，安定 度の状態を検知するためには，すべての初期值をゼ口と した時の出力信号と入力信号々を時間の関数で表わし, それをプラスに変換して比を求めて伝達関数 Transfer Function を算出するのが通例である。ここで入゙力が正 弦波の場合には，その波形の周波数が $0.8 \mathrm{cps}$ 以上にな ると，人間は追従が不能となり，ハンチング状態になる ことを指摘する他，伝達関数と乱調状態の測定式の，人 間，機械の双方への適用を事例に基づき説明している. ここでは手動制御系を設計した場合に適用する諸定数の 定数值のそり方ならびに許容範囲の決定が将来の間題と して残されよう。

終章である第 7 章は「人間工学による設計事例集」で めって内外の適用例を “機械” の種類別にまとめてせ る.「計装」では計器関係の表示方式で目盛, 文字など に触机る他, 計器のニニットに対し計器の配置数, 計器 室の状沉などから諸元を導き出し，建築と同様にモジュ ール Module の概念を与えるべきだと説いている．「生 産機械」では経験的な改善例で, 実験值の適用には至っ ていない、「陸上車輛」では自動車の構造上の最大要件 は視認力でめり，その程度は座席構造に依存することに 加光, 操緹席のメカニズムに言及し, 操縦の安定性の立 場から力学的解析の必要を説いている.「高速道路」で は道路標識ならびに道路照明効果の現状の紹介に止まる が，ここでオペレーションズ・リサーチの利用によるシ ステムとしての交通整理力式の開発に関する解析が附加 されれば, 一層の関心を引くに相違ない。「電子機器新 ょび艦船」では, 電子機器に対し刺激反応機器群, シス
テム群, 各機器と環境条件, 各機器とメインテナンス, 各機器と訓練方式の 5 方向からのアプローチを示唆し, また艦船に括いては動作経済の観点から, 配置された電 子機器に対応した人事配置をリンク解析図であらわして いるが，その効果の測定法が開発されねばならない.

「航空機」については航空計器, コントロール器具に若 干触れる他, シュミレーターの写真紹介に止まるが，こ の方面はわが国でも数年来, 系統的な研究開発が行わ れ, 成果もかなり蓄積されている, 最終の「事務機器特 よび家庭用具」では, 伝達される情報の質, 量を指標に 電話器, 手でキーを操作する事務器群のキーボードの文 字配列, 椅子, Method-Time Measurement 法により 家庭用オブン, 電気レンジ, 作業台, オフィスのレイア ウト，台所のレイアウトなど比較的身近かな問題が，広 範囲に亘り簡単に紹介されている.

本書の果す役目は人間工学の思想の伝達, 概要の紹介 にめって，専門的な資料集として期待すべきではない が, 心理学研究者が一読した際に, 人間側と機械側との. 間の解析のための通路が未完成なのに気づくに違いな いすなわち人間工学の思想的背景となる人間観, 機峨 観が, 発展途次にある境界領域の学間の常として, 出身 領域により相違が見受けられるのであり，また工学側が 機械間の問題を取り扱らシステム・エンジニアリングの 諸技法の人間への適用に対し, 生物科学, 例えば心理学 の確立した手法と蓄積された資料が, 工学側に十分に伝 達されていないのである。統合された同一の手法と術語 に基つく研究開発が行われてこそ, システムの綜合的効 率が高められる. 生物科学者による生物科学の諸技法を も網羅した, 自動, 手動制御に配する人間工学書の上棹 が待望される所以で岁る。

白梅学園短期大学 大川雅司 